\title{
A rapid survey of the invasive plant species in western Angola
}

\author{
Marcel Rejmánek ${ }^{1 *}$, Brian J. Huntley², Johannes J. Le Roux ${ }^{2}$ and David M. \\ Richardson $^{2}$ \\ ${ }^{1}$ Department of Evolution and Ecology, University of California, Davis, CA, 95616, U.S.A. ${ }^{2}$ Centre for Invasion Biology, Department of Botany and \\ Zoology, Stellenbosch University, Matieland, 7602, South Africa
}

\begin{abstract}
Angola is one of the most neglected African countries in terms of botanical research, in respect of both native and naturalized species. We conducted a rapid assessment of invasive plant species in western Angola during August 2014. In thirteen primary vegetation types, we recorded populations of 44 naturalized plant species, nineteen of which are conclusively invasive (spreading far from introduction sites). Dense invasive populations of Chromolaena odorata, Inga vera and Opuntia stricta pose the greatest environmental and economic threats. Some species with known taxonomic and/or biogeographic uncertainties (e.g. Chromolaena odorata and Ageratina adenophora) or which lacked key characteristics for identification such as flowers during our survey (e.g. Eucalyptus spp.) were subjected to DNA barcoding for comparisons with available genetic data from other studies. This approach allowed us to confirm the identity of taxonomically challenging taxa such as Inga vera, Opuntia stricta and Prosopis chilensis, to conclusively differentiate Chromolaena odorata from Ageratina adenophora, and identify the subspecific identity of Acacia saligna. Canonical correspondence analysis was used to assess the presence and abundance of invasive plant species with respect to the major abiotic factors and vegetation types. Three fairly distinct groups of species emerge from this analysis: (i) species of dry lowland habitats (Calotropis gigantea, Leucaena leucocephala and Opuntia stricta); (ii) species of relatively wet habitats at mid elevations (Ageratum conyzoides, Bidens pilosa, Cardiospermum grandiflorum, Chromolaena odorata, Solanum mauritianum and Tithonia diversifolia); and (iii) upland species (Ageratina adenophora, Galinsoga parviflora and Tagetes minuta). Several invasive species that are wide-
\end{abstract}

*Correspondence: E-mail: mrejmanek@ucdavis.edu spread in other tropical and subtropical African countries are currently either missing (e.g. many Australian Acacia species, Azolla filiculoides, Broussonetia papyrifera, Clidemia hirta, Parthenium hysterophorus, Rubus rosaefolius, Salvinia molesta), have only very localized populations in Angola (e.g. Lantana camara, Prosopis chilensis) or exist only as planted individuals (e.g. Acacia mearnsii and A. saligna subsp. saligna).

Key words: biological invasions, invasive species, rapid surveys

\section{Résumé}

L'Angola est actuellement un des pays africains les plus négligés en termes de recherches botaniques, tant pour les plantes indigènes que pour les espèces naturalisées. Nous avons mené une évaluation rapide des espèces invasives dans l'ouest de l'Angola en août 2014. Dans 13 types de végétation primaire, nous avons noté la présence de populations de 44 espèces végétales naturalisées dont 19 étaient, de façon certaine, envahissantes (elles se répandaient loin de leurs sites d'introduction). Ce sont de denses populations envahissantes de Chromolaena odorata, Inga vera et Opuntia stricta qui posent les plus grandes menaces environnementales et économiques. Certaines espèces pour lesquelles subsistent des incertitudes taxonomiques et/ou biogéographiques (ex. Chromolaena odorata et Ageratina adenophora) ou qui ne présentaient pas, au moment de notre étude, les caractéristiques clés (fleurs) qui auraient permis de les identifier (ex. Eucalyptus spp) ont fait l'objet d'une analyse ADN pour les comparer aux données génétiques recueillies par d'autres études. Cette approche nous a permis de confirmer l'identité de taxons difficiles à identifier tels que Inga vera, Opuntia stricta et Prosopis chilensis, de différencier de façon certaine Chromolaena 
odorata d'Ageratina adenophora, et de découvrir l'identité sous-spécifique d'Acacia saligna. Une analyse de correspondance canonique nous a servi pour analyser la présence et l'abondance d'espèces végétales invasives par rapport aux facteurs abiotiques et aux types de végétation majeurs. Trois groupes d'espèces très distincts émergent de cette analyse: (1) des espèces de plaines arides (Calotropis gigantea, Leucaena leucocephala et Opuntia stricta) ; (2) des espèces d'habitats relativement humides de moyenne altitude (Ageratum conyzoides, Bidens pilosa, Cardiospermum grandiflorum, Chromolaena odorata, Solanum mauritianum et Tithonia diversifolia) ; (3) des espèces d'altitude (Ageratina adenophora, Galinsoga parviflora et Tagetes minuta). Plusieurs espèces invasives qui sont répandues dans d'autres pays africains tropicaux et subtropicaux sont actuellement soit absentes (ex. de nombreuses espèces d'Acacia australiennes, Azolla filiculoides, Broussonetia papyrifera, Clidemia hirta, Parthenium hysterophorus, Rubus rosaefolius, Salvinia molesta), soit elles n'ont que des populations très localisées en Angola (ex. Lantana camara, Prosopis chilensis), soit encore n'existent que comme individus plantés (ex. Acacia mearnsii et A. saligna subsp. saligna).

\section{Introduction}

The level of data availability and the general understanding of plant invasions are poor for Sub-Saharan Africa, with the notable exception of South Africa (Henderson, 2007; Moran, Hoffmann \& Zimmermann, 2013; van Wilgen, Davies \& Richardson, 2014). The situation is particularly dire for continental tropical Africa (Foxcroft et al., 2010; Foxcroft, Witt \& Lotter, 2013). Existing analyses of naturalized floras for tropical Africa are largely based on herbarium records (e.g. Stadler et al., 2000; Maroyi, 2012) with most collections generally concentrated around major cities (e.g. see Fig. 1b). Exceptions are the detailed studies by W. Dawson, P.E. Hulme and coworkers from the East Usambara Mountains of Tanzania (Dawson, Burslem \& Hulme, 2009; Hulme et al., 2013) and preliminary surveys from protected areas in Uganda (Rejmánek, 1996; Foxcroft et al., 2010). An extensive report on invasive plants in Namibia also exists (Brown, MacDonald \& Brown, 1985). For Angola, no significant publications on naturalized plants have appeared since the three-part Flora exotica de Angola (Gossweiler, 1948, 1949, 1950). However, even in that publication, about $90 \%$ of species listed were only cultivated and are not naturalized or invasive (for standardized definitions see Table 1). A few cultivated or naturalized species are also mentioned in several volumes of the incomplete Conspectus Florae Angolensis (1931-1993). Between 1961 and 2002 Angola was beset by guerrilla and civil war (Weigert, 2011), and systematic research on native or introduced plants has been very limited.

Recently, a checklist of Angolan vascular plants was published (Figueiredo \& Smith, 2008). Based on this checklist, Figueiredo, Smith \& César (2009) counted 6735 native and 226 'naturalized' vascular plant species in Angola. Unfortunately, there are significant errors in this checklist, especially relating to the categorization of species as 'naturalized' (marked with asterisks in the list). Firstly, based on information in recently published African floras and floras of other continents, it is clear that some nonnative species are recorded as native (e.g. Ageratum conyzoides, Bidens pilosa, Cardiospermum grandiflorum, Chamaesyce prostrata, Diodia spp., Drymaria cordata, Epilobium hirsutum, Indigofera suffruticosa, Mimosa pigra, Mollugo verticillata, Pityrogramma calomelanos, Richardia scabra, Scabiosa columbaria, Sida cordifolia, S. rhombifolia, Sonchus asper, S. oleraceus, Syndrella nodiflora, Vicia hirsuta, Tagetes minuta). Secondly, some species listed as 'naturalized' are only cultivated (e.g. Areca tatechu, Ceratonia siliqua, Cocos nucifera, Dioscorea alata, Mirabilis jalapa, Trapaeolum majus, Zea mays). Thirdly, some native species are treated as nonnative (Achyranthes aspera, Boerhavia diffusa, Bulbostylis barbata, Cassytha filiformis, Flacourtia indica, Rumex abyssinicus). Fourthly, we suspect that many 'naturalized' species have appeared just ephemerally and should rather be classified as 'casual' (sensu Pyšek et al., 2004; Table 1). On the other hand, because of very limited recent field research in Angola, we expected that some invasive, or at least naturalized, plant species (sensu Pyšek et al., 2004; Table 1) remained unrecorded.

Given the rapid escalation of plant invasions in other African countries in the second half of the 20th century (Henderson, 2007; Boy \& Witt, 2013), an assessment of the situation with invasive plants in Angola was clearly overdue. Because travelling in Angola is logistically and financially extremely demanding (Angola is the most expensive African country), our goal was not to make an exhaustive list of naturalized and invasive species of Angola, but to make a rapid assessment of the most prominent and potentially most influential plant invasions across representative vegetation types of western Angola. 
(a)

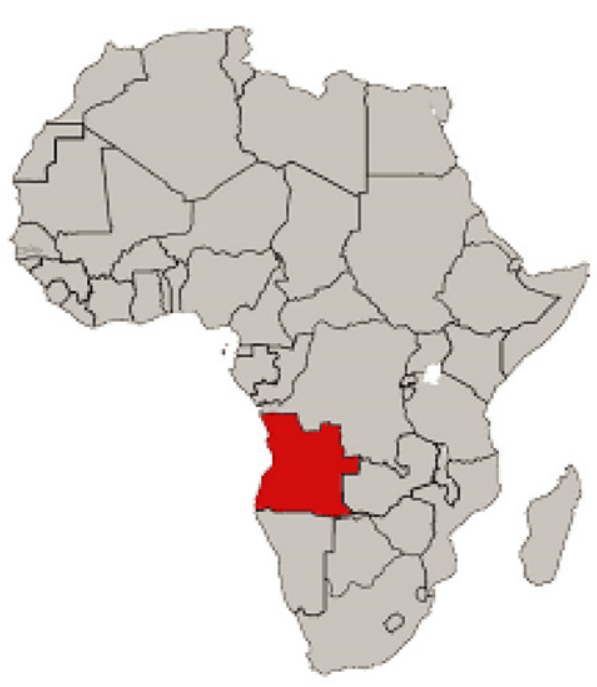

(b)

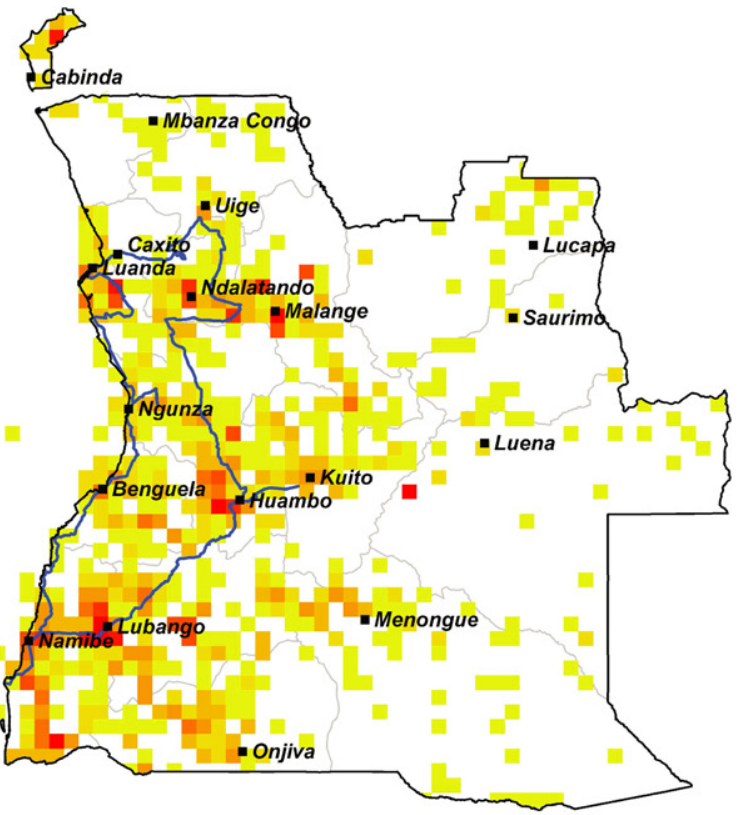

- Route Plant species (GBIF)

$\square$ - 3

- $3-7$

$7-14$

$14-23$

$23-34$

$34-51$

$51-73$

$73-106$

$106-192$ $192-373$

(c)

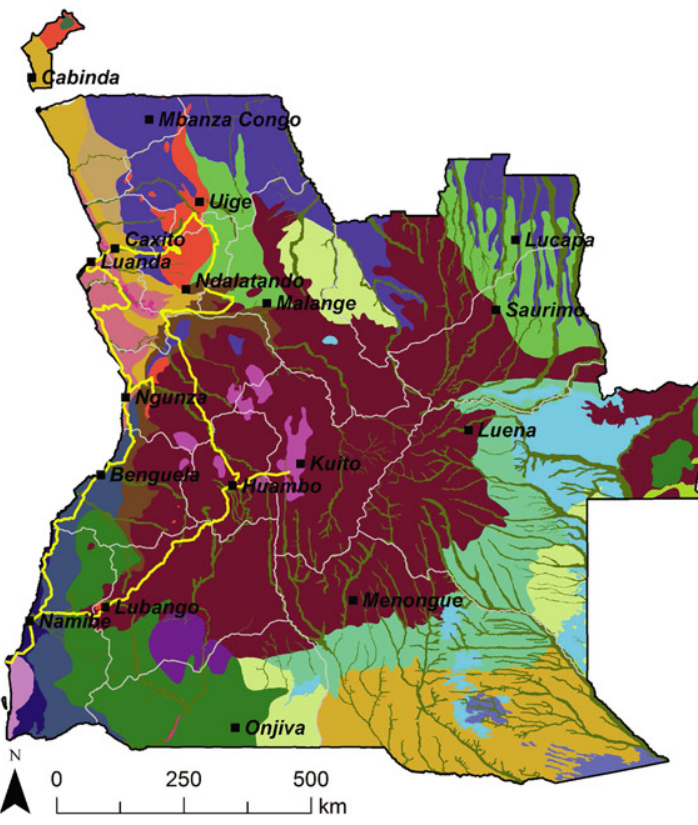

Fig 1 (a) Map of Africa indicating the location of Angola on the continent. (b) Map of Angola indicating the density of all plant collections in Angola registered in the Global Biodiversity Information Facility online repository (http://www.gbif.org/) and the route taken during the survey (in blue). (c) Major original vegetation types in Angola (source: Peace Parks Foundation, South Africa) and the route taken during the survey (in yellow)

\section{Methods, study area and vegetation types}

We visited western Angola during the dry season in the second half of August 2014. The rapid assessment took the form of 162 spot surveys along $3983 \mathrm{~km}$ of major roads in the provinces of Bengo, Benguela, Cuanza Norte, Cuanza Sul, Huambo, Huila, Malange, Namibe and Uige (Fig. 1b). An approximate geographical range of the visited area was $7^{\circ} 36^{\prime} 31^{\prime \prime S}$ to $15^{\circ} 48^{\prime} 14^{\prime \prime S}$ and $11^{\circ} 50^{\prime} 42^{\prime \prime} \mathrm{E}$ to $16^{\circ} 20^{\prime} 19^{\prime \prime} \mathrm{E}$. The selection of routes was performed with the goal of 
Table 1 Standardized terminology in plant invasion ecology (Pyšek et al., 2004)

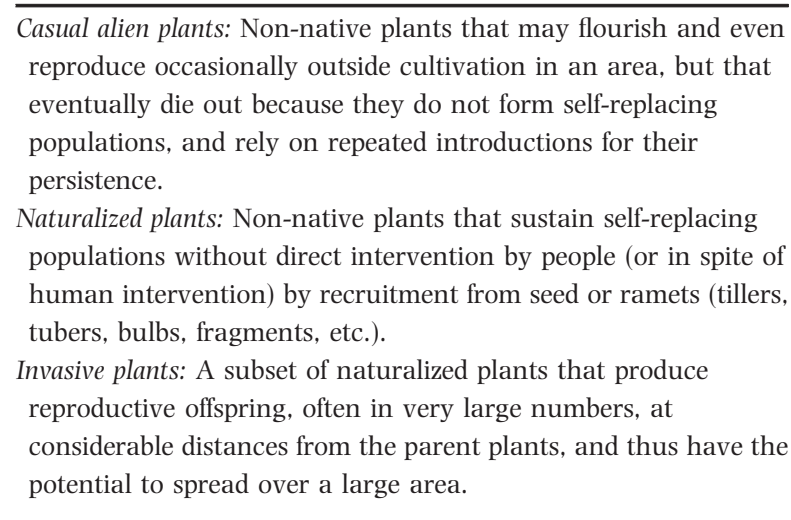

visiting as many vegetation types as possible. For that purpose, the vegetation map of Barbosa at the scale $1: 2,500,500$ (1970) was used to identify key vegetation units for inclusion in the survey. The density of spot surveys was determined by the character of vegetation, by noticeable changes in plant species composition and by the density of noticeable naturalized plant species. The survey team comprised four ecologists: one with expert knowledge over 30 years of the vegetation of Angola (BJH), one with considerable experience of invasive plants in tropical Africa and other tropical regions (MR), and two ecologists with expert knowledge of invasive plants in other parts of southern Africa (JJLR, DMR). Voucher specimens of most of the detected naturalized plant species were deposited in the herbaria of the Instituto Superior de Ciências da Educação (LUB) in Lubango and Stellenbosch University. Our survey covered 13 of the 32 major vegetation types recognized by Barbosa (1970):

3 - Moist semideciduous guineo-zambezian 'cloud forest' (subtypes: 3.1 - Cazengo, 3.2 - Amboim);

9 - Forest-savannah mosaic, 'coffee forest' and zambezian savannah;

11 - Thicket-savannah woodland mosaic of dry forest and savannah;

13 - Thicket-savannah mosaic;

16 - Miombo woodland and grasslands, mostly severely degraded;

17 - Miombo woodlands, medium height;

22 - Savannah/woodland, short to medium, tall grasses;

23 - Tree and shrub savannah - mosaic of woodlands, dry tickets and grasslands;

27 - Arid shrub and tree savannah;
28 - Desert and semidesert dwarf shrublands/karroid;

29 - Desert dunes;

30 - Floodplain grasslands and swamps;

32 - High altitude short grasslands.

The major abiotic, physiognomic and compositional characteristics of these vegetation types are summarized in Appendix 2 (Supporting Information). We coded the abundance of 44 naturalized plant species in each vegetation type as follows: 1 = seen only once as naturalized; 2 = seen more than once naturalized, but no dense stands; $2+=$ as 2 , but also spreading; $3=$ seen more than once and dense; $3+=$ as for 3 , but also spreading. All species categorized as 'spreading' were spreading at least $10 \mathrm{~m}$ away from roads, but mostly in disturbed vegetation (grazed areas, abandoned fields, etc.).

Samples of selected invasive species, especially those with questionable identities and/or known biogeographic uncertainties, were also collected and preserved on silica gel for DNA analyses. We extracted DNA using the CTAB method of Doyle and Doyle (1990) and modified by adding 1\% PVP-40T. Depending on the availability of reference DNA sequence data on the GenBank online repository (ncbi.nlm.nih.gov), we sequenced one or more of the following gene regions for selected species; the internal transcribed spacer region (ITS), maturase $\mathrm{K}$ region (matK), trnL (UAA) 5' exon-trnF (GAA) exon region (trnL-F), ribulose bisphosphate carboxylase large chain (rbcL), external transcribed spacer (ETS). Sequences were edited using BIOEDIT version 7.0.5.3 (Hall, 1999) and blasted against GenBank accessions (http://blast.ncbi.nlm.nih. gov/Blast.cgi.) to determine DNA sequence similarity and identity against available sequence data. For example, we sequenced the ITS region for accessions of putative Ageratina adenophora and Chromolaena odorata due to difficulty in separating these two species from one another in the field in the absence of flowers at some localities and the availability of sequence data in GenBank for both species. We also sequenced gene regions for Eucalyptus spp. (for which definitive field identifications were not conclusive), Inga cf. vera, Opuntia cf. engelmannii, Lantana camara, Acacia saligna and Prosopis cf. glandulosa (for comparisons to known invasive populations from elsewhere in the world). Details for DNA sequencing methodologies are given in Appendix S1. All DNA sequencing data have been deposited in the GenBank online repository (accession numbers KU877443-KU877490).

Because most invasive plant species are usually concentrated in disturbed, highly populated areas, and along 
roads serving these, and because western Angola has been more exposed to non-native plant introductions than the rest of the country, we assume that we had an opportunity to detect most major current plant invasions in Angola.

Average abiotic characteristics of individual vegetation types (mean elevation, mean temperature, coldest month mean temperature, mean annual precipitation and prevailing geological substrata - see Table 2) were derived from Barbosa (1970), Laboratorio Nacional de Investigacao Cientifica Tropical (LNICT, 1974) and Silveria (1967). For visualization, we compiled maps in Arc GIS (ESRI) to indicate our collection route in relation to vegetation types. Canonical correspondence analysis was used to discern the relationships among environmental factors, vegetation types and abundance of naturalized plant species. The Monte Carlo permutation test was used to assess significance of environmental variables for explanation of species distribution using both, conditional effects and marginal effects (using each factor separately). Software CANOCO, version 4.5 was used in these analyses (Ter Braak \& Smilauer, 2002).

\section{Results}

As stated earlier, our survey covered 13 of the 32 major vegetation types recognized by Barbosa (1970).

Our results are summarized in Table 2. Of the 44 taxa listed, thirteen species were not listed by Figueiredo \& Smith (2008): Ageratina adenophora, Antigonon leptopus, Arundo donax, Chromolaena odorata, Eichhornia crassipes, Galinsoga parviflora, Inga vera, Ipomea cf. purpurea, Populus alba, Prosopis chilensis, Psidium guajava, Thevetia peruviana, and Tridax procumbens. However, six of these were already mentioned as being present in the country by Gossweiler (1948): Antigonon leptopus, Arundo donax, Ipomea purpurea, Populus alba, Psidium guajava, and Thevetia peruviana (listed as T. neriifolia). Additionally, Galinsoga parviflora was recently reported from Angola by Monteiro, Henriques \& Moreira (2011) and Chromolaena odorata by Zachariades, van Rensburg \& Witt (2013). Most of the recorded naturalized species are introductions from the Neotropics (33 species), the rest from Asia (6), Europe (3) and Australia (2)

Our DNA sequencing results yielded important insights. First, we confirmed the presence of both Chromolaena odorata (Zachariades, van Rensburg \& Witt, 2013) and Ageratina adenophora (syn. Eupatorium adenophorum, previously unknown from Angola) based on internal transcribed spacer region (ITS) sequences. These two taxa proved difficult to distinguish in the field at some sites where flowers were absent. Our DNA sequencing data indicated that all sequenced accessions from lower elevation areas (ca. $1300 \mathrm{~m}$ above sea level) correspond to $C$. odorata and those from higher lying areas (ca. $2100 \mathrm{~m}$ above sea level) to A. adenophora. The invasive prickly pear was initially identified in the field as Opuntia cf. engelmannii and our DNA sequencing BLAST results based on two chloroplast gene regions, indicated $100 \%$ sequence similarly with both $O$. stricta and O. humifusa. Cactus experts subsequently confirmed $O$. stricta as the likely identity (H.G. Zimmermann and L.C. Majure, pers. communications), and, together with the morphological differences (particularly fruits) between $O$. humifusa and O. stricta, we confirmed the identity of the species as O. stricta. DNA sequencing data identified Acacia saligna in Angola as being subspecies 'saligna' based on phylogeographic data from Thompson et al. (2015). This suggest that nearby countries like South Africa are unlikely to be the source of this species in Angola, as a unique and cultivated genetic lineage, not closely related to any of the four currently recognized subspecies of $A$. saligna, appears to be invasive in South Africa (Thompson et al., 2012). Attempts to confirm the identity of 'Inga cf. vera' by comparing DNA sequences of the specimens we collected (Table 2) to those of Dexter, Pennington \& Cunningham (2010) could not resolve the identity, as our collections showed similar DNA sequence identities to several Inga species. Subsequent expert identification confirmed the identity of the material collected in Angola as Inga vera (T. Pennington, personal communication). DNA sequencing also revealed that the one mesquite species tentatively identified as Prosopis cf. glandulosa in our collections is in fact $P$. chilensis based on molecular data; we therefore adopted the latter classification. Our DNA barcoding approach also confirmed the genetic identities of Cardiospermum grandiflorum and Lantana camara based on trnL-F DNA sequence BLAST results. Three putative Eucalyptus spp., based on BLAST results were in some instances unresolved and confirmed high DNA sequence similarities (99\%) to five species: 1 Angolan spp. as being either E. alaticualus or E. botryoides, $1 \mathrm{spp}$. as E. saligna and $1 \mathrm{spp}$. as being either $E$. brassiana or E. camaldulensis. The latter was identified as $E$. camaldulensis in the field, we therefore adopted this classification.

Of the 44 naturalized species, nineteen are conclusively invasive (marked with ' + ' after their abundance codes in 
Table 2 Abiotic characteristics and abundance rating of naturalized plant species in 14 vegetation types of western Angola.

\begin{tabular}{|c|c|c|c|c|c|c|c|c|c|c|c|c|c|c|}
\hline & \multicolumn{14}{|c|}{ Vegetation Type (BARBOSA 1970) } \\
\hline & 3.1 & 3.2 & 9 & 11 & 13 & 16 & $17 \mathrm{~b}$ & 22 & 23 & 27 & 28 & 29 & 30 & 32 \\
\hline \multicolumn{15}{|l|}{ Abiotic characteristics } \\
\hline Mean elevation $[\mathrm{m}]$ & 900 & 1100 & 600 & 50 & 1200 & 1700 & 1034 & 1200 & 50 & 20 & 50 & 10 & 50 & 2300 \\
\hline Mean temperature $\left[{ }^{\circ} \mathrm{C}\right]$ & 22 & 19.8 & 22.7 & 26.2 & 21.1 & 18.8 & 21.7 & 21.6 & 24.3 & 24.3 & 20 & 21.1 & 24.1 & 14.6 \\
\hline $\begin{array}{l}\text { Coldest month mean } \\
\text { temperature }\left[{ }^{\circ} \mathrm{C}\right]\end{array}$ & 18 & 15.9 & 18.4 & 21.4 & 19.6 & 15.7 & 20.1 & 19.9 & 20.1 & 20 & 15.5 & 14.5 & 19.9 & 11.2 \\
\hline $\begin{array}{l}\text { Mean annual } \\
\text { precipitation }[\mathrm{mm}]\end{array}$ & 1250 & 833 & 914 & 600 & 1470 & 1200 & 760 & 910 & 405 & 184 & 37 & 12 & 335 & 805 \\
\hline Sandstones/sands & & & & & 1 & 1 & & & 1 & 1 & & 1 & & 1 \\
\hline Basic rocks & 1 & 1 & 1 & 1 & 1 & 1 & & 1 & & 1 & 1 & & & \\
\hline Granites & & & & & & 1 & & 1 & & 1 & & & & \\
\hline Quaternary sediments & & & & & & & & & & & & & 1 & \\
\hline Species/native range & \multicolumn{14}{|c|}{ Abundance scores ${ }^{\mathrm{b}}$} \\
\hline $\begin{array}{l}\text { Ageratina adenophora } \\
\text { (Spreng.) King \& Rob. }^{\text {a }} \\
\text { C. America (southern } \\
\text { Mexico) }\end{array}$ & & & & & & 1 & & & & & & & & $2-3+$ \\
\hline $\begin{array}{l}\text { Ageratum conyzoides L. } \\
\text { C. \& trop. S. America }\end{array}$ & $2+$ & $2+$ & $2+$ & & & & & & & & & & & \\
\hline $\begin{array}{l}\text { Albizia lebbeck (L.) Benth. } \\
\text { Tropical Asia, northern } \\
\text { Australia }\end{array}$ & & & & 2 & & & & & & & & & & \\
\hline $\begin{array}{l}\text { Amaranthus hybridus L. } \\
\text { N., C. \& S. America }\end{array}$ & & & & & & 1 & & & & & & & & \\
\hline $\begin{array}{l}\text { Antigonon leptopus } \\
\text { Hook. \& Arn. }^{\mathrm{a}} \\
\text { C. America (Mexico) }\end{array}$ & & & & & & & & & 1 & & & & & \\
\hline $\begin{array}{l}\text { Argemone mexicana L. } \\
\text { C. America }\end{array}$ & & & & & & 2 & 2 & & & 2 & & 1 & & 1 \\
\hline $\begin{array}{l}\text { Arundo donax L. } \\
\text { E. Asia, the } \\
\text { Mediterranean Basin }\end{array}$ & & & & 3 & 3 & 3 & & 3 & 3 & & & & & \\
\hline $\begin{array}{l}\text { Atriplex nummularia Lindl. } \\
\text { Australia }\end{array}$ & & & & & & 1 & & & & & & & & \\
\hline $\begin{array}{l}\text { Bidens pilosa L. var. pilosa } \\
\text { C. America, the Caribbean }\end{array}$ & $2+$ & & & & $2+$ & $2+$ & & & & & & & & \\
\hline $\begin{array}{l}\text { Boerhavia erecta L. } \\
\text { N., C. \& S. America }\end{array}$ & & & & 1 & & & & & & & & & & \\
\hline $\begin{array}{l}\text { Calotropis gigantea } \\
\text { (L.) R. Br. } \\
\text { Asia }\end{array}$ & & & & $2+$ & & & & & $2+$ & & & & & \\
\hline $\begin{array}{l}\text { Canna indica L. } \\
\text { C. \& S. America }\end{array}$ & 1 & & 1 & & & & & & & & & & & \\
\hline $\begin{array}{l}\text { Cardiospermum } \\
\text { grandiflorum Sw. } \\
\text { C. \& S. America, } \\
\text { the Caribbean }\end{array}$ & $2+$ & $2+$ & $2+$ & & $2+$ & & & $2+$ & & & & & & \\
\hline
\end{tabular}

(continued) 
Table 2 (continued)

Vegetation Type (BARBOSA 1970)

\begin{tabular}{llllllllllllll}
\hline 3.1 & 3.2 & 9 & 11 & 13 & 16 & $17 \mathrm{~b}$ & 22 & 23 & 27 & 28 & 29 & 30 & 32
\end{tabular}

Carica papaya L.

1

C. America

Celosia argentea $\mathrm{L}$.

Asia

Chromolaena odorata

(L.) King \& Rob. ${ }^{a}$

C. \& S. America,

the Caribbean

Datura stramonium L.

C. \& S. America

Eclipta prostrata (L.) L.

N., C. \& S. America

Eichhornia crassipes

(Mart.) Solms ${ }^{\mathrm{a}}$

S. America (Brazil)

Eucalyptus camaldulensis

Dehnh.

Australia

Galinsoga parviflora Cav. ${ }^{\mathrm{a}}$

C. \& S. America

Gossypium hirsutum L.

C. \& S. America,

the Caribbean

Inga vera Wild. ${ }^{\mathrm{a}}$

C. \& S. America,

the Caribbean

Ipomaea cf. purpurea

(L.) Roth

C. America (Mexico)

Lantana camara L.

C. \& S. America,

the Caribbean

Leucaena leucocephala

(Lam.) De Wit

C. America

Nicotiana glauca L.

S. America

Nicotiana rustica

Graham

Americas

Opuntia stricta

(Haw.) Haw. ${ }^{\text {a }}$

'N. \& C. America

Parkinsonia aculeata L.

$3+\quad 3+\quad 3+$

$2+$

$3+$

$3+$

N. \& C. America

(continued) 
Table 2 (continued)

\begin{tabular}{|c|c|c|c|c|c|c|c|c|c|c|c|c|c|c|}
\hline & \multicolumn{14}{|c|}{ Vegetation Type (BARBOSA 1970) } \\
\hline & 3.1 & 3.2 & 9 & 11 & 13 & 16 & $17 \mathrm{~b}$ & 22 & 23 & 27 & 28 & 29 & 30 & 32 \\
\hline $\begin{array}{l}\text { Populus alba L. } \\
\text { Europe, W. Asia, } \\
\text { N. Africa }\end{array}$ & & & & & & 3 & & & & & & & & \\
\hline $\begin{array}{l}\text { Prosopis chilensis } \\
\text { (Mol.) Stunz. }^{\text {a }} \\
\text { N. \& C. America }\end{array}$ & & & & & & & & & 1 & & & & & \\
\hline $\begin{array}{l}\text { Psidium guajava L. } \\
\text { C. \& S. America }\end{array}$ & & & & & & & & & & 1 & & 1 & & \\
\hline $\begin{array}{l}\text { Ricinus communis L. } \\
\text { NE Africa and W Asia }\end{array}$ & $2+$ & $2+$ & $2+$ & $2+$ & $2+$ & $2+$ & $3+$ & $2+$ & $2+$ & $2+$ & $2+$ & $2+$ & $2+$ & $2+$ \\
\hline $\begin{array}{l}\text { Senna siamea (Lam.) } \\
\text { Irwin \& Barneby } \\
\text { Indonesia and the } \\
\text { Malay Peninsula }\end{array}$ & $2+$ & $2+$ & $3+$ & $2+$ & & & & & & & & & & \\
\hline $\begin{array}{l}\text { Sida cordifolia L. } \\
\text { Asia }\end{array}$ & & & & & & & & & 1 & & & & & \\
\hline $\begin{array}{l}\text { Sida rhombifolia L. } \\
\text { the New World tropics }\end{array}$ & & & & & & $2+$ & & & & & & & & \\
\hline $\begin{array}{l}\text { Solanum mauritianum } \\
\text { Scop. } \\
\text { S. America }\end{array}$ & $2+$ & $2+$ & $2+$ & & $2+$ & $2+$ & & $2+$ & & & & & & \\
\hline $\begin{array}{l}\text { Sonchus oleraceus L. } \\
\text { Eurasia }\end{array}$ & & & & & & & & & & & 1 & & & \\
\hline $\begin{array}{l}\text { Synedrella nodiflora } \\
\text { (L.) Gaertn. } \\
\text { C. \& S. America, } \\
\text { the Caribbean }\end{array}$ & 1 & & & & & & & & & & & & & \\
\hline $\begin{array}{l}\text { Tagetes minuta L. } \\
\text { S. America }\end{array}$ & & & & & & $2+$ & & & & & & & & \\
\hline $\begin{array}{l}\text { Thevetia peruviana } \\
\text { (Pers.) K. Schum. }^{\text {a }} \\
\text { C. \& S. America }\end{array}$ & & & & & & 1 & & & & & & & & \\
\hline $\begin{array}{l}\text { Tithonia diversifolia } \\
\text { (Hemsl,) A. Grey } \\
\text { C. America }\end{array}$ & $3+$ & $3+$ & $3+$ & $3+$ & $3+$ & 2 & $3+$ & & & & & & & $2+$ \\
\hline $\begin{array}{l}\text { Tridax procumbens L. } \\
\text { C. \& S. America }\end{array}$ & $2+$ & & & $2+$ & & & & $2+$ & $2+$ & 1 & & & & \\
\hline
\end{tabular}

${ }^{\mathrm{a}}$ Species not listed in Figueiredo \& Smith (2008).

${ }^{\mathrm{b}}$ Abundance coding: 1 - seen only once as naturalized; 2 - seen more than once naturalized, but no dense stands; $2+-$ as 2 , but also spreading; 3 - seen more than once and dense stands; $3+-$ as 3 but also spreading.

Table 1). The most frequent invasive species is the cosmopolitan invader, Ricinus communis. It is commonly present in all visited vegetation types, and forms dense, but spatially limited stands. The other most frequently recorded invasive species (present in more than five vegetation types) are Argemone mexicana, Arundo donax,
Cardiospermum grandiflorum, Chromolaena odorata, Inga vera, Solanum mauritianum, Tithonia diversifolia and Tridax procumbens. In terms of spatial extent and density of the recognized naturalized plant species, invasions of Opuntia stricta, Chromolaena odorata and Inga vera are currently most impressive and worrying (Fig. 2). Dense infestations 


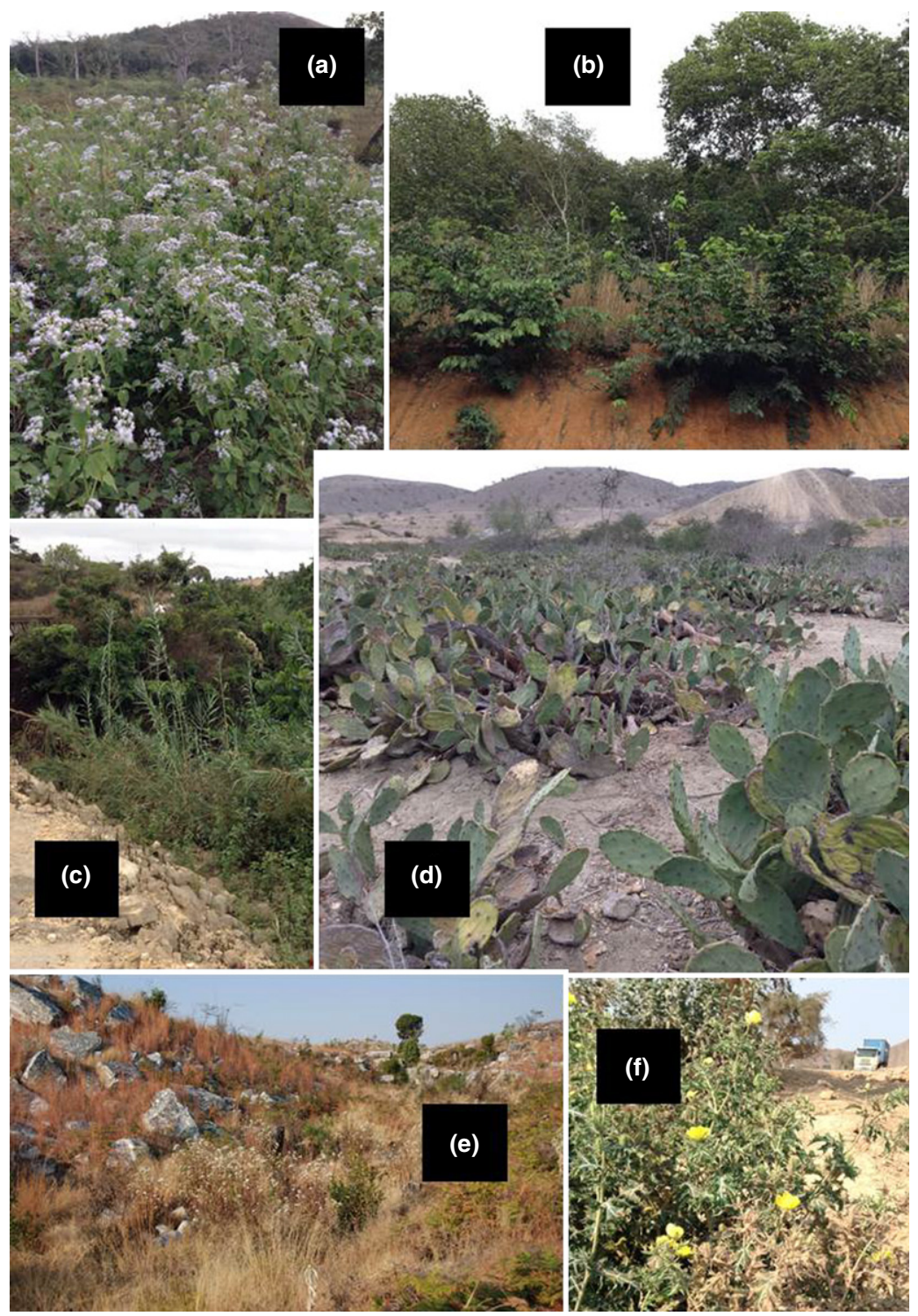

Fig 2 Examples of invasive alien plant species in Angola. (a) Chromolaena odorata; (b) Inga vera; (c) Arundo donax; (d) Opuntia stricta; (e) Ageratina adenophora; (f) Argemone mexicana

of the first two cover hundreds of hectares, mostly in pastures and abandoned agricultural land. Inga vera seems to be still mostly localized, forming dense stands only at a few sites.

There is clear, nonrandom association between recognized naturalized plant species and major vegetation types (Table 2). Relationships between naturalized species (present in at least two vegetation types), major abiotic factors and vegetation types are summarized in the canonical correspondence ordination diagram (Fig. 3). The major gradient is determined by precipitation (increasing from right to left). The Monte Carlo permutation test for conditional effects shows the impact of precipitation to be highly significant $(P=0.004)$. The second most important factor is mean temperature $(P=0.016)$, and the third is soil type (sandstone/sand, $P=0.032$ ). This implies that besides precipitation and temperature, substrate $\mathrm{pH}$ may play some role in shaping the distribution of naturalized 
plant species. In terms of marginal effects (evaluating each factor separately), precipitation, elevation and mean temperature are equally important (lambda $=0.35$ ). This is a result of the strong negative correlation between elevation and mean temperature, which is apparent from corresponding vectors in Fig. 3.

Three fairly distinct groups of species emerge from this analysis: (i) dry lowland species (Calotropis gigantea, Leucaena leucocephala and Opuntia stricta, mostly in vegetation types 23 and 27); (ii) species of relatively wet habitats at middle elevations (Ageratum conyzoides, Bidens pilosa, Cardiospermum grandiflorum, Chromolaena odorata,

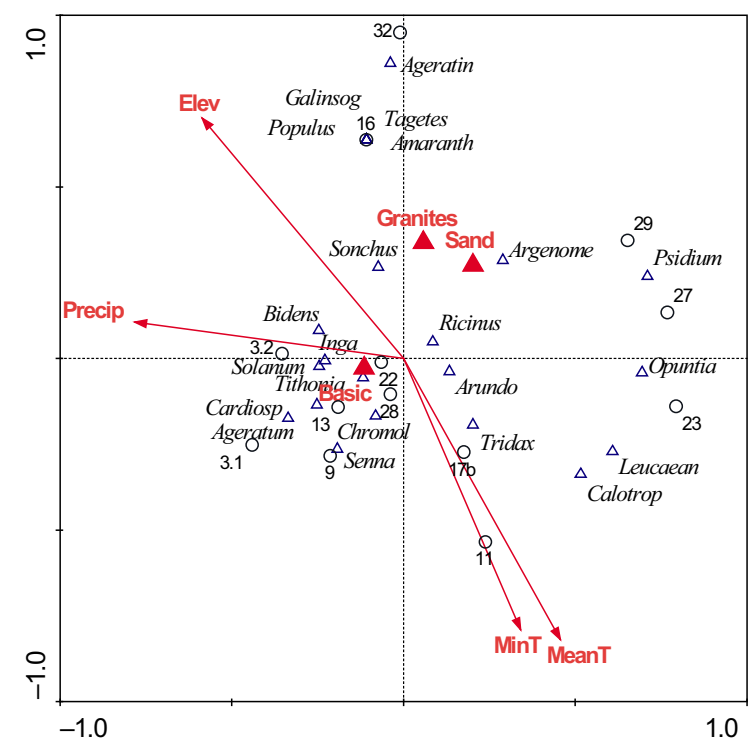

Fig 3 Canonical correspondence analysis ordination of frequently naturalized plant species with respect to vegetation types and selected abiotic factors in western Angola. Triangles: Ageratin $=$ Ageratina $\quad$ adenophora,$\quad$ Ageratum $=A . \quad$ conyzoides, Amaranth = Amaranthus hybridus, Argemone $=A . \quad$ mexicana, Arundo $=$ A. donax, Bidens $=$ B. pilosa, Calotrop $=$ Calotropis gigantea, Cardiosp $=$ Cardiospermum grandiflorum, Chromol $=$ Chromolaena odorata, Galinsog $=$ Galinsoga parviflora, Inga $=I$. vera, Leucaena $=$ Leucaena leucocephala, Opuntia $=0$. stricta, Populus $=P . \quad$ alba,$\quad$ Psidium $=P . \quad$ guajava,$\quad$ Ricinus $=R . \quad$ communis, Tagetes $=T$. minuta, Tithonia $=T$. diversifolia, Tridax $=T$. procumbens. Arrows indicate the direction and relative importance (arrow length) of the continuous environmental variables (Elev = elevation, MeanT $=$ mean temperature, $\mathrm{MinT}=$ minimum temperature, $\quad$ Precip $=$ precipitation $)$. Triangles indicate centroids of nominal environmental variables $($ Basic $=$ basic rocks, Granites, Sand $=$ Sandstones and sands). Circles indicate centroids of habitat types (see text and Appendix S2)
Solanum mauritianum and Tithonia diversifolia, mostly in vegetation types 3, 9, 13 and 22); and (iii) upland species (Ageratina adenophora, Galinsoga parviflora and Tagetes minuta, mostly in vegetation types 16 and 32).

\section{Discussion}

Despite the temporal and spatial limitations of our rapid assessment, some important results emerged from this survey. Compared to other African countries, the total number of naturalized plant species (species forming selfreplacing populations without human assistance) in Angola is relatively low. For example, large parts of Angola are climatically and environmentally very similar to South Africa's savannah biome (Richardson \& Thuiller, 2007), which is severely invaded by many alien plant species (Richardson et al., 1997; Henderson, 2007). Current estimates of the numbers of naturalized vascular plant species in Angola and nine other African countries within a similar latitudinal range are summarized in Table 3. Considering the size of the country, its coastal position and environmental heterogeneity, Angola has a relatively low number of naturalized plant species. Despite the low number of invasive species and the low overall extent of plant invasions, at least three species that are clearly invasive (spreading) represent major environmental and economic threats.

Chromolaena odorata (Asteraceae) has been present in several Asian and African countries, as well as on some oceanic islands, since the beginning of the 20th century (de Rouw, 1991; Gautier, 1992; Henderson, 2007; Raimundo et al., 2007; Koutika \& Rainey, 2010; Kueffer et al., 2010; Boy \& Witt, 2013; Paterson \& Zachariades, 2013; Zachariades, van Rensburg \& Witt, 2013; Zheng et al., 2013). In Angola, however, it very likely arrived much more recently and was probably introduced by Cuban soldiers participating in the civil war since 1975 (see George, 2005). This species has caused widespread ecosystem-level impacts in South African savannahs (te Beest, Esler \& Richardson, 2015) and is likely to replicate such impacts in Angola.

Opuntia stricta (Cactaceae) is listed among the 100 of the world's worst plant and animal invaders (Lowe et al., 2004) and is an aggressive invader in many parts of the world including Africa (e.g. Foxcroft et al., 2004; Strum, Sterling \& Mutunga, 2015). This species forms extensive invasive stands in vegetation types 23 and 27 in Angola (Fig. 2). Invasions seem to be associated with overgrazed 
Table 3 Reported numbers of naturalized vascular plant species (NVPS) in Angola and other African countries/regions within similar latitudinal ranges.

\begin{tabular}{llll}
\hline Country & Area $\left(\mathrm{km}^{2}\right)$ & NVPS & Source \\
\hline Angola & $1,246,700$ & ca 230 & Figueiredo, Smith and César (2009) \& this study \\
Dem. Rep. Congo & $2,344,858$ & 522 & van Kleunen et al. (2015) \\
Madagascar & 587,041 & 546 & Kull et al (2012) \\
Mozambique & 799,380 & ca 400 & da Silva, Izidine and Amude (2004) \\
Namibia & 824,292 & $164\left(218^{\mathrm{a}}\right)$ & Klaassen \& Kwembeya (2013) \\
South Africa & $1,220,813$ & 915 & Germishuizen et al. (2006) \\
St. Helena & 122 & ca 250 & Lambdon (2012) \\
Usambara Mts. (Tanz.) & 3,200 & 239 & Iversen (1991) \\
Zambia & 752,618 & ca 130 & Phiri (2005) \\
Zimbabwe & 390,757 & 238 & Maroyi (2012) \\
\hline
\end{tabular}

${ }^{\mathrm{a}}$ Includes species of uncertain status.

pastures, and it spreads both by seeds and vegetatively from detached cladodes. Because of its density, this species is now an excellent candidate for biological control. Initial attempts to control $O$. stricta biologically with two herbivorous insects Cactoblastis cactorum (Lepidoptera, Phycitidae) and Dactylopius opuntiae (Homoptera, Dactylopiidae) were not successful in South Africa. Fortunately, the new biotype of D. opuntiae ('stricta') was imported to South Africa, tested and released in 1997. This biotype has become abundant in the vicinity of the release sites and has caused considerable local suppression of $O$. stricta (Hoffmann, Moran \& Zimmermann, 1999). There are at least three other Opuntia species present in Angola (Gossweiler, 1949; Figueiredo \& Smith, 2008), but we were not able to evaluate their invasion status.

To our knowledge, this survey provides the first published evidence of Inga vera (Fabaceae, Mimosoideae) as invasive and spreading beyond its native range in Central and South America (Pennington, 1997). As with several other fast-growing Inga species in other parts of the tropics (see Pennington \& Fernandes, 1998), I. vera was introduced to Angola as a shade tree in coffee plantations. However, this species seems to be spreading rapidly, especially in abandoned coffee plantations, with sporadic mechanical control underway in some areas. This is only the second species of this large genus (over 250 species) reported as invasive, the other being $I$. spectabilis (Vahl) Willdenow (Rejmánek \& Richardson, 2013). Two taxa (I. affinis DC. = I. vera Willd. subsp. affinis (DC.) T.D. Penn and I. edulis Mart.) were reported from Angola by Figueiredo \& Smith (2008), but these records are questionable, given the difficulty of identifying species in this genus.
A few other species are spreading and form dense stands locally (e.g. Ageratina adenophora, Ricinus communis, Senna siamea, Solanum mauritianum, Tithonia diversifolia). However, their immediate environmental or economic impacts seem to be rather limited. Only Ageratina adenophora invades undisturbed plant communities of high altitude short grasslands far from any roads or other human created disturbances (Fig. 2e).

An interesting feature of non-native flora of western Angola is the conspicuous absence of some species that are highly invasive in many other African countries (e.g. Australian Acacia species; Azolla filiculoides, Broussonetia papyrifera, Clidemia hirta, Parthenium hysterophorus, Rubus rosaefolius, Salvinia molesta). Some other well-known invaders are commonly cultivated, but are not (yet) invasive at all (Melia azedarach, Pinus patula, P. pinaster, Tecoma stans), or are spreading only at very few locations (Lantana camara, Prosopis chilensis). Lantana camara was recorded near human habitations at many localities but no invasions were noted, in marked contrast to the situation in South African savannahs where this species is one of the most widespread invaders (Vardien et al., 2012). A single specimen of the highly invasive Mimosa pigra was listed by Figueiredo \& Smith (2008), but we did not note this species in the field. Consistent with the situation in many other countries (Rejmánek \& Richardson, 2011), we noted no invasions of Eucalyptus species. More than 40 species of this genus have been introduced to Angola, several of which were grown in plantations (Gossweiler, 1949; Poynton, 1979), including very large plantings along the Benguela railway line (Delgado-Matas \& Pukkala, 2011). At one site, we recorded about twenty seedlings of $E$. camaldulensis, all less than $30 \mathrm{~m}$ from planted trees. Even 
along drainage lines, in habitats where E. camaldulensis is widely invasive in South Africa (Forsyth et al., 2004), we found no naturalized plants. The relatively low number of naturalized and invasive plant species in Angola may be explained by relative isolation of this country during the second part of the last century. Even now, tourism in Angola is very limited compared with other African countries and the probability of spontaneous introduction and dissemination of alien species by camping tourists is low.

In conclusion, the three most pronounced invaders (Chromolaena odorata, Inga vera and Opuntia stricta) are currently so widespread that their eradication is not feasible (Rejmánek \& Pitcairn, 2002). Local mechanical/ chemical control and biological control are the only options (Malfokoane, Zimmermann \& Hill, 2007; Zachariades et al., 2011; Moran, Hoffmann \& Zimmermann, 2013). If it is true that Parthenium hysterophorus and Salvinia molesta are not yet present in Angola, every effort should be made to prevent their introduction into the country. Both species represent very serious environmental and economic threats (Howard \& Harley, 1998; McConnachie et al., 2010; Boy \& Witt, 2013; Adkins \& Shabbir, 2014). Ideally, planting of all non-native species of Acacia, Caesalpinia, Clidemia, Miconia, Mimosa, Opuntia and Prosopis should be prohibited. We noted several planted species which are highly invasive elsewhere in the world, including other African countries (e.g. Casuarina equisetifolia, A. mearnsii, A. saligna); these should be carefully monitored in the future. For example, the planting of Acacia mearnsii (invasive wherever it has been planted outside its native range) as a shade tree in the parking area at Tundavala near Lubango, in an area earmarked as a future National Park, is regrettable.

\section{Acknowledgements}

The financial support of the National Geographic Society (NGS Conservation Trust Grant \#C273-14), the Oppenheimer Memorial Trust and the DST-NRF Centre of Excellence for Invasion Biology is gratefully acknowledged. DMR received additional support from the National Research Foundation, South Africa (grant 85417). We are most grateful to Beat Weber of Navimbuando, Huambo, for his excellent field support. We thank Dr Fernanda Lages and her colleagues at the ISCED Herbarium in Lubango and Dr Terry Pennington (Royal Botanic Gardens, Kew) and Dr Lucas Majure (Desert Botanical
Garden, Phoenix) for assistance with plant identifications. Megan Koordom (Centre for Invasion Biology, Stellenbosch University) assisted with DNA sequencing of specimens. We thank Vernon Visser and Heidi Hirsch for assistance with maps and Christoph Kueffer for useful comments on the manuscript.

\section{References}

AdKINs, S. \& SHABBIR, A. (2014) Biology, ecology and management of invasive parthenium weed (Parthenium hysterophorus L.). Pest Manag. Sci. 70, 1023-1029.

Barbosa, L.A.G. (1970) Carta Fitogeográfica de Angola. Instituto de Investigacao Cientifíca de Angola, Luanda.

te Beest, M., Esler, K.J. \& Richardson, D.M. (2015) Linking functional traits to impacts of invasive plant species: a case study. Plant Ecol. 216, 293-305.

Boy, G. \& WITT, A. (2013) Invasive Alien Plants and Their Management in Africa. CABI Africa, Nairobi, Kenya, 177 pp.

Brown, C.J., MacDonald, I.A.W. \& Brown, S.E. (eds) (1985) Invasive alien organisms in South West Africa/Namibia. South African National Scientific Programmes Report No. 119.

Dawson, W., Burslem, D.F.R.P. \& Hulme, P.E. (2009) Factors explaining alien plant invasion success in a tropical ecosystem differ at each stage of invasion. J. Ecol. 97, 657-665.

Delgado-Matas, C. \& Pukkala, T. (2011) Comparison of the growth of six Eucalyptus Species in Angola. Int. J. For. Res. Article ID 980259, doi:10.1155/2011/980259.

DeXter, K.G., Pennington, T.D. \& Cunningham, C.W. (2010) Using DNA to assess errors in tropical tree identifications: How often are ecologists wrong and when does it matter? Ecol. Monogr. 80, 267-286.

Doyle, J. \& Doyle, J. (1990) Isolation of plant DNA from fresh tissue. Focus 12, 13-15.

Figueiredo, E. \& SMith, G.F. (2008) Plants of Angola/Plantas de Angola. Strelitzia 22, 1-279.

Figueiredo, E., Smith, G.F. \& CésAr, J. (2009) The flora of Angola: first record of diversity and endemism. Taxon 58, 233-236.

Forsyth, G.G., Richardson, D.M., Brown, P.J. \& VAN WiLgen, B.W. (2004) A rapid assessment of the invasive status of Eucalyptus species in two South African provinces. S. Afr. J. Sci. 100, 7577.

Foxcroft, L.C., WitT, A. \& LotTer, W.D. (2013) Icons in peril: Invasive alien plants in African protected areas. Plant Invasions in Protected Areas: Patterns, Problems and Challenges (Eds L. C. Foxcroft, P. Pyšek, D. M. Richardson and P. Genovesi) pp 117143. Springer, Dordrecht.

Foxcroft, L.C., Rouget, M., Richardson, D.M. \& Mac Fadyen, S. (2004) Reconstructing 50 years of Opuntia stricta invasion in the Kruger National Park, South Africa: environmental determinants and propagule pressure. Divers. Distrib. 10, 427437. 
Foxcroft, L.C., Richardson, D.M., RejMÁneK, M. \& PYŠEK, P. (2010) Alien plant invasions in tropical and sub-tropical savannas: patterns, processes and prospects. Biol. Invasions 12, 39133933.

GAUTIER, L. (1992) Taxonomy and distribution of a tropical weed: Chromolaena odorata (L.) R. King \& H. Robinson. Candollea 47, 645-662.

George, E. (2005) The Cuban Intervention in Angola, 1965-1991: From Che Guevara to Cuito Cuanavale. Frank Cass, London. Germishuizen, G., Meyer, N.L., Steenkamp, Y. \& Keith, M. eds. (2006) A Checklist of South African Plants. Southern African Botanical Diversity Network Report No. 41. SABONET, Pretoria. GossweILER, J. (1948, 1949, 1950) Flora exótica de Angola. Agronomia Angolana 1, 122-198; 2, 174-255; 3, 144-167.

HALL, T.A. (1999) BioEdit: a user-friendly biological sequence alignment editor and analysis program for Windows 95/98/NT. Nucleic Acids Symp. Ser. 41, 95-98.

HENDERSON, L. (2007) Invasive, naturalized and casual alien plants in southern Africa: a summary based on the Southern African Plant Invaders Atlas (SAPIA). Bothalia 37, 215-248.

Hoffmann, J.H., Moran, V.C. \& Zimmermann, H.G. (1999) Integrated management of Opuntia stricta (Haworth) Haworth (Cactaceae) in South Africa: an enhanced role for two, renowned, insect agents. In: Biological Control of Weeds in South Africa (1990-1998) (Eds T. Olckers and M. P. HiLL). Afr. Entomol. Mem. 1, 15-20.

HowARD, G.W. \& HARLEY, K.L.S. (1998) How do floating aquatic weeds affect wetland conservation and development? How can these effects be minimized?. Wetlands Ecol. Manage. 5, 215-225.

Hulme, P.E., Burslem, D.F.R.P., Dawson, W., Edward, E., Richard, J. \& Trevelyan, R. (2013) Aliens in the Arc: Are invasive trees a threat to the montane forests of East Africa? Plant Invasions in Protected Areas: Patterns, Problems and Challenges (Eds L. C. Foxcroft, P. PyšeK, D. M. Richardson and P. Genovesi). pp 145165. Springer, Dordrecht.

IvERSEN, S.T. (1991) The Usambara Mountains, NE Tanzania: phytogeography of vascular plant flora. Acta Universitatis Upsaliensis Symbolae Botanicae Upsalienses 9, 1-234.

Klaassen, E. \& Kwembeya, E. (2013) A Checklist of Namibian Indigenous and Naturalized Plants. Occasional Contributions No. 5. National Botanical Research Institute, Windhoek.

van Kleunen, M., Dawson, W., Essl, F., Pergl, J., Winter, M., Weber, E., Kreft, H., Weigelt, P., Kartesz, J., Nishino, M., Antonova, L.A., Barcelona, J.F., Cabezas, F.J., Cárdenas, D., Cárdenas-Toro, J., Castaño, N., Chacón, E., Chatelain, C., Ebel, A.L., Figueiredo, E., Fuentes, N., Groom, Q.J., Henderson, L., InDERJIT, X.X., Kupriyanov, A., Masciadri, S., Meerman, J., Morozova, O., Moser, D., Nickrent, D.L., Patzelt, A., Pelser, P.B., Baptiste, M.P., Poopath, M., Schulze, M., Seebens, H., Shu, W., Thomas, J., Velayos, M., Wieringa, J.J. \& PYšEK, P. (2015) Global exchange and accumulation of non-native plants. Nature 525, 100-104.

KoutiKa, L.S. \& RAINEY, H.J. (2010) Chromolaena odorata in different ecosystems: weed or fallow plant? Appl. Ecol. Environm. Res. 8, 131-142.
Kueffer, C., Daehler, C.C., Torres-Santana, C.W., Lavergne, C., MeYer, J-Y., OtTo, R. \& SILVA, L. (2010) A global comparison of plant invasions on oceanic islands. Perspect. Plant Ecol. Evol. Syst. 12, 145-161.

Kull, C.A., Tassin, J., Morea, S., Ramiarantsoa, R., Blanc-Pamard, C. \& CARriere, S.M. (2012) The introduced flora of Madagascar. Biol. Invasions 14, 875-888.

Lambdon, P. (2012) Flowering Plants \& Ferns of St Helena. Pisces Publications, St Helena.

LNICT (1974) Carta Geológica de Angola. Laboratorio Nacional de Investigacao Cientifica Tropical, Lisboa.

Lowe, S., Browne, M., Boudjelas, S. \& De Poorter, M. (2004) 100 of the World's Worst Invasive Alien Species. A selection from the Global Invasive Species Database. The Invasive Species Specialist Group (ISSG) a Specialist Group of the Species Survival Commission (SSC) of the World Conservation Union (IUCN), Gland, Switzerland.

MalfokoAne, L.D., Zimmermann, H.G. \& HiLl, M.P. (2007) Development of Cactoblastis cactorum (Berg) (Lepidoptera: Pyralidae) on six North American Opuntia species. Afr. Entomol. 15, 295-299.

Maroyi, A. (2012) The casual, naturalized and invasive alien flora of Zimbabwe based on herbarium and literature records. Koedoe 54(1), Art. \#1054, 6 pp.

McConnachie, A.J., Strathie, L.W., Mersie, W., Gebrehiwot, L., Zewdie, K., Abdurehim, A., Abrha, B., Araya, T., Asaregew, F., Assefa, F., Gebre-Tsadik, R., Nigatu, L., Tadesse, B. \& Tana, T. (2010) Current and potential geographical distribution of the invasive plant Parthenium hysterophorus (Asteraceae) in eastern and southern Africa. Weed Res. 51, 71-84.

Monteiro, A., Henrioues, I. \& Moreira, I. (2011) Critical period for weed control in potatoes in the Huambo Province (Angola). Planta Daninha 29, 351-362.

Moran, V.C., Hoffmann, J.H. \& Zimmermann, H.G. (2013) 100 years of biological control of invasive alien plants in South Africa: History, practice and achievements. S. Afr. J. Sci. 109, Article a0022.

PAterson, I.D. \& Zachariades, C. (2013) ISSRs indicate that Chromolaena odorata invading southern Africa originates in Jamaica or Cuba. Biol. Cont. 66, 132-139.

Pennington, T.D. (1997) The genus Inga: Botany. The Royal Botanic Gardens, Kew, (844 pp.).

Pennington, T.D. \& Fernandes, E.C.M. (eds) (1998) The Genus Inga: Utilization. The Royal Botanic Gardens, Kew (167 pp.).

PHIRI, P.S.M. (2005) A Checklist of Zambian Vascular Plants. Southern African Botanical Diversity Network Report No. 32. SABONET, Pretoria.

Poynton, R.J. (1979) Tree Planting in Southern Africa. Vol. 2. The Eucalyptus. Department of Forestry, Pretoria.

PyšEK, P., Richardson, D.M., RejMÁNEK, M., Webster, G.L., WiLLIAMSON, M. \& KiRSCHNER, L. (2004) Alien plants in checklists and floras: toward better communication between taxonomists and ecologists. Taxon 53, 131-143. 
Raimundo, R.L.G., Fonseca, R.L., Sachachetti-Pereira, R., Peterson, A.T. \& Lewinson, T.M. (2007) Native and exotic distribution of Siamweed (Chromolaena odorata) model using the genetic algorithm for rule-set production. Weed Sci. 55, $41-48$.

RejMÁNeK, M. (1996) Species richness and resistance to invasions. Biodiversity and Ecosystem Processes in Tropical Forests (Eds G.

OriansR. Dirzo and J. H. Cushman). pp 153-172. Springer, New York.

RejMÁneK, M. \& Pitcairn, M.J. (2002) When is eradication of exotic plant pests a realistic goal? Turning the Tide: The Eradication of Invasive Species (Eds C. R. Veттсн and M. N. Clout). pp 249-253. IUCN, Gland, Switzerland and Cambridge, UK.

RejMÁNEK, M. \& Richardson, D.M. (2011) Eucalypts. Encyclopedia of Biological Invasions (Eds D. SimberLoff and M. RejMÁneK). pp 203209. California University Press, Berkeley.

Rejmánek, M. \& Richardson, D.M. (2013) Trees and shrubs as invasive alien species - 2013 update of the global database. Divers. Distrib. 19, 1093-1094.

Richardson, D.M. \& Thuiler, W. (2007) Home away from home objective mapping of high-risk source areas for plant introductions. Divers. Distrib. 13, 299-323.

Richardson, D.M., Macdonald, I.A.W., Hoffmann, J.H. \& HeNDERson, L. (1997) Alien plant invasions. Vegetation of Southern Africa (Eds R. M. Cowling, D. M. Richardson and S. M. PierCE). pp 535-570. Cambridge University Press, Cambridge.

DE Rouw, A. (1991) The invasion of Chromolaena odorata (L.) King \& Robinson (ex Eupatorium odoratum), and competition with the native flora, in a rain forest zone, south-west Cote d'Ivore. J. Biogeogr. 18, 13-23.

da Silva, M.C., Izidine, S. \& Amude, A.B. (2004) A Preliminary Checklist of the Vascular Plants of Mozambique. South African Botanical Diversity Network Report No. 20. SABONET, Pretoria.

Silveria, M. (1967) Climas de Angola. Servico Meteorologico de Angola. Mimeo, Luanda, 43 pp.

Stadler, J., Trefflich, A., Klotz, S. \& Brandl, R. (2000) Exotic plant species invade hot-spots: Alien flora of north-western Kenya. Ecography 23, 169-176.

Strum, S.C., Sterling, G. \& Mutunga, S.K. (2015) The perfect storm: land use change promotes Opuntia stricta's invasion of pastoral rangelands in Kenya. J. Arid Environ. 118, 37-47.

Ter BraAk, C.J.F. \& SMILAuER, P. (2002) CANOCO Reference Manual and CanoDraw for Windows User's Guide: Software for Canonical Community Ordination (Version 4.5). Microcomputer Power, Ithaca.
Thompson, G.D., Bellstedt, D.U., Byrne, M., Millar, M.A., Richardson, D.M., WiLson, J.R.U. \& LE Roux, J.J. (2012) Cultivation shapes genetic novelty in a globally important invader. Mol. Ecol. 21, 3187-3199.

Thompson, G.D., Bellstedt, D.U., Richardson, D.M., Wilson, J.R.U. \& LE RouX, J.J. (2015) A tree well-travelled: global genetic structure of the invasive tree Acacia saligna. J. Biogeogr. 42, 305314.

Vardien, W., Richardson, D.M., Foxcroft, L.C., Thompson, G.D., WiLson, J.R.U. \& LE Roux, J.J. (2012) The introduction history, spread, and current distribution of Lantana camara in South Africa. S. Afr. J. Bot. 81, 81-94.

Weigert, S.L. (2011) Angola: A Modern Military History, 19612002. Palgrave Macmillan, New York.

VAN WiLgen, B.W., DAviES, S.J. \& Richardson, D.M. (2014) Invasion science for society: a decade of contributions from the Centre for Invasion Biology. S. Afr. J. Sci., 110, Number 7/8, Art. A0074.

Zachariades, C., van Rensburg, S.J. \& WitT, A.B.R. (2013) Recent spread and new records of Chromolaena odorata in Africa. Proceedings of the Eight International Workshop on Biological Control and Management of Chromolaena Odorata and Other Eupatoriae (Eds C. Zachariades, L. W. Strathie, M. D. Day and R. MuniaPPAn). pp 20-27. ARC-Plant Protection Research Institute, Pretoria.

Zachariades, C., Strathie, L.W., Retief, E. \& Dube, N. (2011) Progress towards the biological control of Chromolaena odorata (L.) R.M.King \& H.Rob. (Asteraceae) in South Africa. African Entomol. 19, 282-302.

Zheng, Y., Feng, Y., Liao, Z., Li, W., Xiao, H. \& Sui, H. (2013) Invasive Chromolaena odorata has similar size but higher phenolic concentration than native conspecifics. Evol. Ecol. Res. 15, 769-781.

(Manuscript accepted 3 March 2016)

doi: 10.1111/aje.12315

\section{Supporting information}

Additional Supporting Information may be found in the online version of this article:

Appendix S1 Details for DNA sequencing methodologies. Appendix S2 Summary description of Barbosa (1970) vegetation types visited in August 2014. 